\title{
Legal Issues of China's Possible Participation in the International Space Station: Comparing to the Russian Experience
}

\section{Yun Zhao*}

China has made great achievements in space activities in recent years. While emphasizing the principle of self-independence, China also acknowledges the importance of space cooperation. As early as 2001, China indicated its interest in joining the International Space Station. However, no substantive progress has been made concerning China's participation thus far. This may be a result of political and economic, rather than legal and technical, considerations. There is no doubt that China's participation shall contribute to the sustainable development of the ISS. China's participation could also offer an excellent opportunity to reexamine the 1998 framework and clarify or improve certain provisions that exist in the current regime. While technologically ready for participation, China should start considering possible legal issues that may arise from its participation in the ISS project. This article takes up the challenging task of identifying potential legal issues that may arise in the course of China's participation in the ISS and offers suggestions for a future cooperative legal framework regarding the ISS.

\section{Keywords}

International Space Station, Space Cooperation, Inter-Governmental Agreement, Outer Space Treaty

* Associate Professor of International Law at the University of Hong Kong. LL.B. (CUPL), LL.M. (CUPL/Leiden), Dr.iur. (Erasmus). This article stems in part from a paper presented at the International Astronautical Congress 2011 at Cape Town, South Africa during October 3-7, 2011. This research was supported by the HKU Seed Funding Program for Basic Research. The author may be contacted at: zhaoy@hku.hk / Address: Cheng Yu Tung Tower, Faculty of Law, The University of Hong Kong, Pokfulam, Hong Kong. 


\section{Introduction}

The International Space Station ("ISS"), an excellent example of multilateral space cooperation, is the largest and most complex manned space cooperative project in the human history.ermanently manned multi-use facility in low Earth orbit ("LEO") for the purpose of scientific and technological research. ${ }^{1}$ The Partner States contribute to the construction of the ISS and share equally the benefits arising out of activities in the ISS. Various researchers have indicated the importance of the ISS in not only contributing to scientific and technological development, but also furthering the development of space laws. ${ }^{2}$

China has made great achievements in space activities in recent years. It has developed a concrete plan for space exploration in order to build national space station by $2020{ }^{3}$ While emphasizing the principle of self-independence, China also acknowledges the importance of space cooperation. ${ }^{4}$ Bilaterally, China has reached cooperation agreements with many countries; multilaterally, China hosts the AsiaPacific Space Cooperation Organization (“APSCO”). ${ }^{5}$

Since 2001, China has indicated its interest in joining the ISS. ${ }^{6}$ While the United States vetoed China's participation early on, China's rapid technological development and international cooperation with regard to outer space activities have led to increased cooperation between the two countries. President Barak Obama's visit to China in 2009 resulted in a press release announcing Chinese-American Rapprochement in the space field. ${ }^{7}$ Recently, the European Space Agency ("ESA") also indicated its support for China's inclusion in the ISS. ${ }^{8}$ All these positive

1 L. Myers, The International Space Station: Canada's Involvement, available at http://dsp-psd.pwgsc.gc.ca/ Collection-R/LoPBdP/CIR/875-e.htm (last visited on Apr. 6, 2013).

2 The Intergovernmental Agreement for the International Space Station was considered the latest space law treaties to enter into force. See C. Petras, "Space Force Alpha": Military Use of the International Space Station and the Concept of "Peaceful Purposes," 53 A. F. L. Rev. 160 (2002).

3 See China Planning Space Station Launch in 2010, Redorbit (Oct. 27, 2010), available at http://www.redorbit.com/ news/space/1938804/china_planning_space_station_launch_in_2020 (last visited on Apr. 6, 2013).

4 Information Office of the State Council of the People's Republic of China, China's Space Activities in 2006 (2006).

5 See the official website of the Asia-Pacific Space Cooperation Organization, available at http://www.apsco.int (last visited on Apr. 9, 2013).

6 Staff Writer, China Eyes Entry to ISS Project, SpaCE DAILY, May 1, 2001, available at http://www.spacedaily.com/news/ china-01zd.html (last visited on Apr. 6, 2003). See also C. Covault, China Seeks ISS role, Accelerates Space Program, 155(20) Chinese Space Power 52 (2001).

7 See A China-USA Space Co-operation Programmes?, EnJoy SPACE, Nov. 18, 2009, available at http://www.enjoyspace. $\mathrm{com} / \mathrm{en} /$ news/a-china-usa-space-co-operation-programme (last visited on Apr. 6, 2013).

8 Staff Writer, China May Become Space Station Partner, Space Travel, Jun. 2, 2010, available at http://www.space-travel. com/reports/China_May_Become_Space_Station_Partner_999.html (last visited on Apr. 6, 2013). 
signs show that China has a great chance to become part of the ISS. As such, both the ISS Partner States and China should all prepare for China's future possible participation in the ISS. Although technologically ready for possible participation, China should begin seriously considering the potential legal issues involved with such participation.

The main purpose of this article is to take up this challenging task by identifying possible legal issues in China's participation in the ISS and offer suggestions for future cooperative legal framework of the Station. This paper consists of five parts including Introduction and Conclusion. Part two will examine the possibility and significance of China's participation in the ISS. Part three will look into legal issues that may arise with China's participation in the ISS. Three legal issues are identified for analysis in this part such as legal framework, institutional, and operational issues. As far as the issue of participation in the ISS is concerned, China and Russia share similarities. Both have advanced space technologies and Russia joined the ISS only after the original framework had been in existence for several years. Examinations of Russia's participation process can offer a useful lesson for China. The discussions in Part three accordingly make reference to Russia's participation in the ISS and the changes brought to the legal regime for the ISS at that time. Part four will move further to examine issues such as democratization of the ISS legal regime, understanding of peacefulness, State responsibility, and the dispute settlement mechanism.

\section{Significance of the China's Participation in the ISS}

China has shown great interest in participating in the ISS since 2001. ${ }^{9}$ If China participates in the ISS project, various options at different cooperative levels would exist as follows: (1) The Partner States can invite an astronaut of a non-Partner State to visit the ISS; (2) they can allow a spacecraft of a non-Partner State to dock to the ISS on a regular basis; or (3) they can go further and allow a full partnership for a non-Partner State. ${ }^{10}$ The US has so far vetoed China's participation, ${ }^{11}$ which,

9 Staff Writer, supra note 6.

10 D. Mindell et al., The Future of Human Spaceflight: Objectives and Policy Implications in a Global Context 65 (2009), available at http://carnegie.org/fileadmin/Media/Publications/PDF/spaceFuture.pdf (last visited on Apr. 6, 2013).

11 The United States has in mind the following three possible options for China: 1. continue the non-cooperative attitude; 2. cooperative efforts step-by-step; and 3. propose a 'grand bargain,' an overall cooperative framework, including military, civil and commercial use of outer space. For details, see T. Hitchens \& D. Chen, Forging $a$ 
it believes, may pose "technical and safety challenges, as well as questions of technology transfer." ${ }^{12}$ Other reasons may include China's political system, its lack of transparency, and perceived poor human rights record. Closely related to the issue of transparency, the US is also suspicious of China's policies and rules regarding technology transfer and threats of weaponization in outer space. ${ }^{13}$ All these concerns account for China's failure to join the Missile Technology Control Regime ("MTCR").

A given State's political system and human rights regime are often barriers to space technological cooperation. However, a regular dialogue platform has been set up for the leaders of the US, the EU and China to exchange their views on human rights. Thus, the key issue rests on the concerns over 'technological transfer.' China has already established a rather complete domestic legal regime for export controls. This regime is largely in line with international standards. Internationally, China is already a member to the Treaty on the Non-Proliferation of Nuclear Weapons ("NPT") and has signed the Comprehensive Test Ban Treaty. ${ }^{14}$ While China has declared its intention to become a member to the MTCR and obviously enacted similar rules as the Regime, China has not yet been admitted to the MTCR. As a result, political and economic, rather than legal and technical, considerations take up a more important role.

Members are taking a more pragmatic approach in admitting a new member. Possible technical or commercial benefits or any foreseeable interests from a potential membership can rule over political or human rights considerations. In this respect, China's participation in the ISS appears all the more realistic. China, as the third country to have sent a human being to outer space, holds advanced technologies for space activities; its indigenous space technologies have the potential to bring about new revolutionary developments, commercial or technical, to the operation and management of the ISS. China's efforts in developing an effective export control regime and determination to comply with the international legal regime can help to alleviate the concerns over the illegal transfer of sensitive technologies. A total

\footnotetext{
Sino-US “Grand Bargain” in Space, 24 Space Policy 128-131 (2008); J. Johnson-Freese, A New US-Sino Space Relationship, 4(2) Astropolitics 155 (2006).

12 Supra note 10 , at 65.

13 J. Acuthan, China's Outer Space Programme: Diplomacy of Competition or Co-operation?, China PersPeCtive, available at $\mathrm{http} / /$ chinaperspectives.revues.org/document577.html (last visited on Apr. 6, 2013). See also R. Dellios, China's Space Program: A Strategic and Political Analysis, 7 The Culture Mandala (Dec. 2005), available at http:// www.international-relations.com/CM7-1WB/ChinasSpaceWB.htm (last visited on Apr. 6, 2013).

14 J. Yuan, New Player in the Game: China, Arms Control, and Multilateralism, in China Turns to Multilateralism: Foreign Policy and Regional Security 58 (G. Wu \& H. Lansdowne eds., 2008).
} 
exclusion of China is not beneficial to any party. Previous experience shows that excluding China from high-tech areas will not prevent China from developing advanced technologies on its own. Cooperation, instead of confrontation, would bring more practical and immediate benefits to all parties. ${ }^{15}$

The Obama administration has been actively interested in the Sino--US space cooperation. It was, however, overshadowed by the NASA appropriations bill in early May 2011. ${ }^{16}$ This congressional prohibition shared the same concern as the minds behind the veto of China's participation in the MTCR. It was criticized as "pointless isolation gestures." ${ }^{17}$ The effect of the ban is an open question. John Holdren has argued that: "The ban did not apply to the President's ability to conduct foreign policy." ${ }^{18}$ There are indications that the Obama administration and the president's appointed administrator of the NASA, Charlie Bolden, would like to get around that ban. ${ }^{19}$ The administration planned to obey the prohibition as long as it did not conflict with the president's authority to conduct foreign relations. ${ }^{20}$

It is in the interests of the US to cooperate with China with regards to the ISS. Allowing China to visit the ISS would "require the Chinese to build new facilities, such as a tracking station to cover the ISS orbit, and work hard at gaining experience necessary for such a rendezvous. ${ }^{21}$ China would have to open up its program to Western experts to demonstrate its safety. ${ }^{22}$ It is consistent with the transparency principle to be upheld in the future Inter-Governmental Agreement ("IGA"). Consequently, optimistic attitudes could be held towards China's participation in the ISS.

15 M. Wall, NASA Chief Says US Could Cooperate with China in Space, SPACE.com, Nov. 3, 2011, available at http://www.space.com/13492-china-united-states-space-cooperation-nasa.html (last visited on Apr. 6, 2013).

16 A BILL-Making appropriations for the Department of Defense and the other departments and agencies of the Government for the fiscal year ending September 30, 2011, and for other purposes. See The draft Bill, available at http://www.nss.org/HR-2112-final.pdf (last visited on Apr. 6, 2013).

17 J. Johnson-Freese, US-China Space Cooperation: Congress' Pointless Lockdown, China-US Focus, Jun. 10, 2011, available at $\mathrm{http} / / \mathrm{www}$. chinausfocus.com/peace-security/us-china-space-cooperation-congress $\% \mathrm{E} 2 \% 80 \% 99$-pointlesslockdown (last visited on Apr. 6, 2013).

18 Id.

19 C. Moskowitz, US \& China: Space Race or Cosmic Cooperation?, SPACE.com, Sep. 27 2011, available at http:// www.space.com/13100-china-space-program-nasa-space-race.html (last visited on Apr. 6, 2013).

20 Id.

21 D. Day, The Benefits of A New Space Race, The Space Rev, Apr. 26, 2004, available at http://www.thespacereview. com/article/137/1 (last visited Apr. 6, 2013).

22 Id. 


\section{Legal Issues}

\section{A. Legal Framework}

The ISS was originally an US program. As early as 1984, the US developed the idea of deploying a permanent manned space station. ${ }^{23}$ Three Memoranda of Understanding ("MOUs") were signed in 1985 with the European Space Agency ("ESA"), Japan and Canada, respectively. They added an international dimension to this program. ${ }^{24}$ Although there are fifteen member States in the ISS, they represent only four Partners, because the eleven member States constituting the ESA are treated as one single 'European Partner. ${ }^{, 25}$

The drastic change of the political status quo in the 1990s, especially the end of the Cold War, paved the way for Russia's participation in the ISS. The expanded program finally required an appropriate legal framework for the sustainable development of space cooperative projects. The basic legal framework of the ISS can be divided into three layers. First, the IGA sets up the fundamental principles and structure for the ISS. ${ }^{26}$ The original version of the IGA was completed in 1988, with the US taking the leading role. The current version was reached in 1998 after Russia's participation in the ISS. ${ }^{27}$ This is the case as the IGA establishes "a framework of principles and procedures, with the details to be continually addressed and adjusted." ${ }^{28}$ Second, the MOUs were concluded between the NASA and each of the other cooperating agencies of the ISS partners to further address unresolved matters for the operation of the ISS. Third, the Partner States reached various implementing arrangement to carry out the MOUs, which defined the contractual obligations and trading of partners' rights and duties. ${ }^{29}$

23 S. Rosmalen, The International Space Station Past, Present and Future: An Overview, in The International Space Station: Commercial Utilization from a European Legal Perspective 9-14 (F. Dunk \& M. Brus eds., 2006).

24 A. Farand, The Space Station Cooperation Framework, 94 ESA Bulletin (May 1998), available at http://www.esa. int/esapub/bulletin/bullet94/FARAND.pdf (last visited on Apr. 6, 2013).

25 See Agreement concerning Cooperation on the Civil International Space Station [hereinafter The 1998 IGA] pmbl., Jan. 29, 1998, T.I.A.S. 12927.

26 For details on the IGA provisions, see A. Yakovenko, The Intergovernmental Agreement on the International Space Station, 15 Space Policy 82-84 (1999).

27 See International Space Station Legal Framework, ESA, Oct. 24, 2008, available at http://www.esa.int/Our_Activities/ Human_Spaceflight/International_Space_Station/International_Space_Station_Legal_Framework (last visited on Apr. 6, 2013).

28 L. Cline \& G. Gibbs, Re-Negotiation of the International Space Station Agreements 1993-1997, 53 Acta Astronautica 917-925 (Dec. 2003).

29 The 1998 IGA art. 4. 
The above three layers of documents create contractual obligations on issues such as management, operation, utilization and development of the ISS. ${ }^{30}$ Additionally, internal rules have been drafted to deal with astronauts' acts and general operational matters within the ISS. ${ }^{31}$ Aside from the above three layers of documents specifically designed for the ISS, the existing space treaties and general principles of space law are still applicable to the ISS. ${ }^{32}$

Each Partner retains jurisdiction and control over the elements it registers and personnel in or on the ISS that are its nationals. It also has the opportunity to extend the application of domestic laws to the above elements and personnel. ${ }^{33}$ Consequently, while putting forward a general legal framework for the ISS, the IGA fails to fully provide a set of homogeneous rules for specific activities carried out in the ISS. Instead, the Agreement leaves matters, such as the protection of intellectual property rights and the exchange of data and goods, to national legal regimes. ${ }^{34}$

\section{B. Institutional Concerns: Inferring from the Russian Experiences}

In recent years, with rapid development in space technologies, China has often been presented as the competitive opponent of the US in the new race to outer space. China is the third country to have developed an independent manned space mission and has set out a clear goal of building its own space station. As the Americans and the Europeans have obviously realized that China's participation in the ISS could contribute to the development of the ISS in the future, their attitudes have been gradually changing. ${ }^{35}$

China's possible participation in the ISS is likely to raise new legal questions that have not been directly dealt with so far. As a reference, it might be useful to consider briefly the legal issues that arose when Russia joined the ISS in the 1990s.

30 See The IGA and its Respective MOUs, available at $\mathrm{http} / / / \mathrm{www}$. spacelaw.olemiss.edu/JSL_34_2.html (last visited on Apr. 6, 2013). For details on the Legal Framework of the ISS, see supra note 26, at 79-86.

31 See 14 CFR Part 1214 Code of Conduct for the International Space Station Crew, Space REF, Dec 21, 2000, available at http://www.gpo.gov/fdsys/pkg/FR-2000-12-21/html/00-32381.htm (last visited on Apr. 10, 2013).

32 F. Dunk, The International Legal Framework for European Activities on Board the ISS, in The INTERnational Space Station: Commercial Utilization from a European Legal Perspective 15-20 (Dunk \& Brus eds., 2006).

33 The 1998 IGA art. 5.

34 Supra note 27.

35 G. Abbey \& L. Chiao, Time for the US to Partner with China in Space?, Discovery News, Dec 13, 2012, available at http://news.discovery.com/space/private-spaceflight/opinion-nasa-partner-china-politics-spaceflight-gap-121127.htm (last visited on Apr. 6, 2013). 
The drastic changes that took place in the political climate as a result of the end of the Cold War created the opportunity for global space cooperation. In particular, Russia was a vital country that had highly advanced space technologies and space facilities for the further development of the ISS, but needed sufficient financial support from the ISS Partner States. The complementary needs between the two sides made Russia join the ISS. They finally reached consensus after several rounds of negotiations. ${ }^{36}$

Before Russia's participation, the ISS was largely reliant on the American technologies and financial contributions; the other Partner States were only joining the American base station with their own important space elements. ${ }^{37}$ It is thus natural that the original IGA signed in 1988 emphasized the controlling role of the US and ultimate authority lay with the US. Russia, however, raised many questions during the negotiations based on its highly advanced and technologies. ${ }^{38}$ Finally, the 1988 IGA was replaced by a new legal framework (hereinafter The 1998 IGA). Compared to the 1988 IGA which gave the US precedence in decision-making, the 1998 IGA put more of an emphasis on the principle of equal partnership. ${ }^{39}$ The members had finally achieved a mutually acceptable solution by adjusting their positions in areas such as command and control of the station. ${ }^{40}$ The Partner States have guaranteed that their shares would commensurate their contribution to the development and implementation of the ISS. A separate MOU with the Russian Space Agency ("RSA") provided that, in the event of non consensus, the final decision would be made by the NASA. However, should RSA disagree, the decision would not apply to its part of the station. ${ }^{41}$ Consequently, the revised regime, while taking into consideration the investments from the all the Partner States, provides a comparatively more important role for Russia and the US with regard to the jurisdiction and control over the ISS. ${ }^{42}$ This is commensurate with the contributions

\footnotetext{
36 For Russia's participation process, see M. Lindroos (updated by M. Wade), International Space Station, available at http://www.astronautix.com/craft/intation.htm (last visited on Apr. 6, 2013).

37 See International Space Station: US Space Station History, available at http://www.readyed.com.au/Sites/skylab.html (last visited on Apr. 6, 2013).

38 M. Devlin \& W. Schmidt, Legal Issues Continue to Surround the International Space Station, 8 USAFA J. LEG. STUD. 247 (1997).

39 MOU art. 8.1. For details, see From Cold War to International Cooperation - the Story of the ISS, DLR, available at http://www.dlr.de/iss/en/desktopdefault.aspx/tabid-1945/2746_read-4182/gallery-1/gallery_read-Image.19.2296 (last visited Apr. 6, 2013).

40 The 1998 IGA at art. 5. The basic rule is that "each Partner shall retain jurisdiction and control over the elements it registers and over personnel in or on the Space Station who are its nationals."

41 MOU art. 8.1.

42 Supra note 38 , at 247.
} 
from these two Partners and the size of their crews on board the ISS. In view of US' ground control over the ISS, it is understandable that the US still retains a primary role in command and control of the ISS. ${ }^{43}$

Criminal jurisdiction was one of the major areas for negotiation. Generally, there are four theories of international criminal jurisdiction: (1) subjective/objective territorial jurisdiction; (2) nationality jurisdiction; (3) protective jurisdiction; and (4) universal jurisdiction. ${ }^{44}$ The 1988 IGA adopted territorial jurisdiction as the major principle, which is supplemented by the principle of nationality jurisdiction. The Partner States were to have criminal jurisdiction over their own flight elements and their own nationals. ${ }^{45}$ However, the US enjoyed a secondary exclusive right to exercise criminal jurisdiction over "misconduct committed by a non-US national in or on a non-US element of the manned base or attached to the manned base which endangers the safety of the manned base or the crew members thereon." ${ }^{46}$ Such a special status with regard to criminal jurisdiction again strengthened the US' controlling role in the old regime.

Russia's participation led to discussions over how to balance the rights and obligations of Partner States. Furthermore, Russia needed the guarantee of jurisdiction over its own nationals. As a result, nationality jurisdiction took priority with the Partners exercising jurisdiction over their own nationals. ${ }^{47}$ The US under the new regime could still exercise criminal jurisdiction over nationals of another Partner State, but only when the concerned Partner State failed to provide assurances of prosecution. ${ }^{48}$ This was drastically different from the old regime where the US could exercise such jurisdiction by merely claiming that it failed to receive assurances of prosecution. ${ }^{49}$ As such, the burden of proof lay on the provider of assurances, instead of the receiver; such a shift "therefore continues the move towards fairness and equality." 50

Nationality jurisdiction is complemented by a protective principle, namely, the passive personality jurisdiction in which the Partner States shall carry out

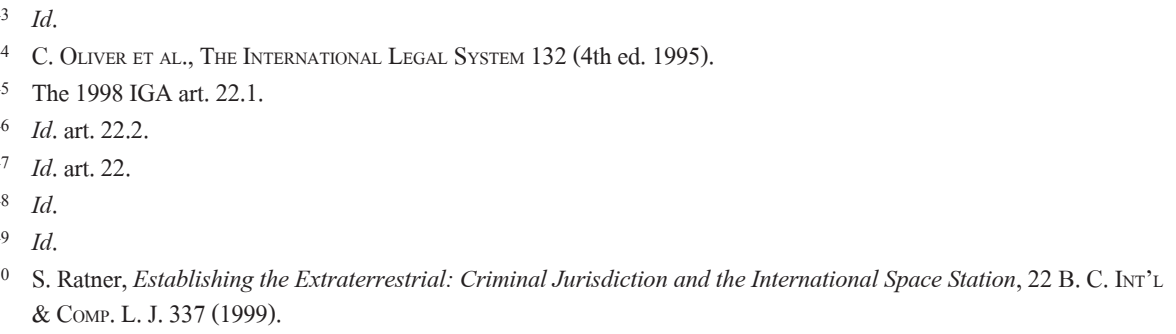


consultation and try to resolve conflicts, if any, in a friendly manner. ${ }^{51}$ So, a Partner State may request consultation with another Partner State, seeking to exercise territorial jurisdiction over a national of the other Partner State who perpetrated a crime in its territory. ${ }^{52}$ This represents the cooperative effort in exercising criminal jurisdiction as the 1998 IGA further provides that "each Partner State shall, subject to its national laws and regulations, afford the other Partners assistance in connection with alleged misconduct on orbit." 53

Extradition, never an important issue before Russia's participation, became a sensitive question for negotiation. This had to do with Russia's history and social system. Legally, a State shall have an obligation to prosecute or extradite once a crime comes under the "jurisdiction nexus of universal interest." ${ }^{54}$ Examples of such crimes include hijacking, piracy, genocide and crimes against humanity. ${ }^{55}$ Under the new regime, however, the Partner States successfully included the extradition provision under the section of criminal jurisdiction, which provided for the possibility of the 1998 IGA to serve as the legal basis for extradition for crimes outside the scope of universal jurisdiction. ${ }^{56}$ No separate extradition agreement was needed for extradition of criminals onboard the ISS. Thus, a compulsory regime was created for the extradition. ${ }^{57}$ Such an arrangement is considered to demonstrate "a deep commitment to mutual cooperation and genuine desire to make the ISS project

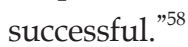

This arrangement is especially meaningful to China since extradition, for China, has always been a difficult and sensitive area to reach any bilateral or multilateral agreements with other States. This extradition provision under the IGA, while limited to issues related to the ISS, can work as a testing bed for China's future negotiations regarding extradition arrangements with other States.

Intellectual property protection arose as another important area. No changes, however, were made to this area; the Partner States still retain the right to obtain intellectual property rights in all those produced in any part of the ISS. ${ }^{59}$ This

The 1998 IGA art. 22.2.

52 Id. art. 22.4 .

53 Id.

54 Supra note 50, at 337.

55 For details on the Universal Jurisdiction, see M. InAZumi, Universal Jurisdiction in Modern International Law: Expansion of National Jurisdiction for Prosecuting Serious Crimes under International Law 99 (2005); B. Oxman, Jurisdiction of States, 4 Max Planck Encyclopedia of Public International Law 552-554 (R. Wolfrum ed., 2012).

56 The 1998 IGA art. 22.3.

57 Id.

58 Supra note 50 , at 338 .

59 The 1998 IGA art. 21. 
provision is not to be confused with the provision on exchange of data and goods. The negotiations successfully led to the provision that all the Partner States shall make efforts to share the data and goods of their research, but special consideration shall be taken to the profits of the investors and the interests of the investing State. ${ }^{60}$ This provision, largely representing Russian Interests, on the one hand, sticks to the principle of information sharing; on the other hand, it balances the interests and benefits of the investing States and other Partner States. The arrangement is understandable since the Partners and private entities in those Partner States should be able to obtain sufficient return on their investments, instead of freely sharing their discoveries. ${ }^{61}$ This issue is closely connected with the proper design of space commercial framework to effectively apply the term "common heritage of mankind" inscribed in the Moon Agreement. ${ }^{62}$

The IGA put down for the first time a provision regarding liability. Article 16 of the 1998 IGA deals with the application of the Liability Convention in possible liability scenarios. However, the 1998 IGA partly modifies the provision on crosswaiver of liability. Cross-waiver of liability by the Partner States is defined to be the general rule for the purpose of encouraging participation of Partner States in the exploration, and use of outer space through the ISS. ${ }^{63}$ Each Partner State shall waive all claims against "(1) another Partner State, (2) a related entity of another Partner State, and (3) the employees of either, when damage arises out of Protected Space Operations. ${ }^{\prime 64}$ As such, some related entities are included in this cross-waiver regime. The definition of the term 'related entities' was expanded in the 1998 IGA. $^{65}$ This term is defined to include: (1) a contractor or subcontractor of a Partner State at any tier; (2) a user or customer of a Partner State at any tier; and (3) a contractor or subcontractor of a user or customer of a Partner State at any tier. It may also apply to a State, or an agency or institution of a State. ${ }^{66}$ That means, the cross-waiver regime can be extended to non-Partner sovereign States under certain circumstances. Such an expanded definition satisfies Russia's expectations. Since Russia sometimes carries out its launching activities in Ukraine, it is possible to extend the cross-waiver

$60 \quad$ Id. art. 19.

61 Chukeat Noichim, The Protection of Intellectual Property Rights in Outer Space of the EU and Thailand, THAILAND LAW FORUM, available at http://www.thailawforum.com/articles/ipspacenoichim.html (last visited on Apr. 6, 2013).

62 See Agreement Governing the Activities of States on the Moon and Other Celestial Bodies of 1979 art. 11.1, Dec. 18, 1979, 1363 U.N.T.S. 21; 18 I.L.M. 1434 (1979); 18 U.S.T. 2410.

63 The 1998 IGA art. 16.1.

64 Id. art. 16.

$65 I d$. art. 16.2.

66 Id. 
of liability to Ukraine, a non-Partner State. Also, the Liability Convention shall apply in any other situation, i.e., when the liability involves any third party, not belonging to Partner States and related entities. ${ }^{67}$ The liability issue under such circumstances shall be decided on a case-by-case basis. As one scholar has correctly observed, consequently, "overall, the spirit of cooperation has resulted in the need for each partner State and their related entities to simply accept the possibility that they may suffer damage in the context of the ISS without being able to assert a liability claim for the purpose." 68

\section{Operational System}

Russia joined the ISS at a time when it was facing economic difficulties after the end of the Cold War. This might have minimized their negotiation power leaving the leadership of the US as an integral part of the ISS. In contrast, China has now harnessed advanced space technologies and is developing its own space programs. Moreover, China's participation in the ISS shall exert substantial influence on the everyday operations of the Station. It is thus expected, in the future, a more cooperative framework stressing the equal role of all the Partners States, instead of the dominant role of the US and Russia, in the management and operation of the ISS. Optimistically, the current framework of the ISS can be more open than the 1998 framework. Eventually, China's possible participation offers an excellent opportunity to reexamine the 1998 framework and clarify or improve certain provisions that exist in the current regime. As far as China is concerned, it will be necessary to seriously study the 1998 IGA and to see if there are any necessary changes or improvements. At the same time, China should study its current situation and examine whether any preparations on its part are needed for participation in the ISS. ${ }^{69}$

Because participation in the ISS is a venture, the costs should not outweigh the benefits. ${ }^{70}$ Considering the huge operating and maintenance costs, and its capability to have its own control network, China will be in a position to negotiate for a better

67 Convention on International Liability for Damage Caused by Space Objects arts. 2 \& 3, Mar 29, 1972, 961 U.N.T.S. 187; 24 U.S.T. 2389; 10 I.L.M. 965 (1971). See also Dunk \& Brus eds., supra note 32, at 267.

68 F. von der Dunk, Space Law in the Age of the International Space Station, in Humans IN OUTER SPACE-INTERDISCIPLINARY Odysseys 157 (L. Codignola-Bo \& K. Schrogl eds., 2009).

69 J. Rhian, Can China Enter the International Space Family?, Universe Today, Jan. 10 2011, available at http://www. universetoday.com/82368/can-china-enter-the-international-space-family (last visited on Apr. 6, 2013).

70 D. Legacey, Is the International Space Station Really Worth It?, Policy Options 73-77 (Mar. 2011), available at http://www.irpp.org/po/archive/mar01/legacey.pdf (last visited on Apr. 9, 2013). 
result in order to justify the costs. Cost should be proportionate to the benefits of the investment. If not, no country would be willing to be an ISS partner. Thus, China shall value highly the principle of balance of rights and obligations during the negotiations for the participation in the ISS. While China does not aspire to be a leader or to outdo the US and Russia, its contribution should be fully reflected in the management and operation of the ISS. ${ }^{71}$

As defined in the IGA, utilization rights of the ISS come from the contribution of user elements, infrastructure elements, or both. Any Partner shall retain the use of the user elements it provides; any provider of infrastructure elements shall receive, in exchange, a fixed share of the use of certain user elements. ${ }^{72}$ When it comes to infrastructure elements, Russia keeps 100 percent of the utilization rights in these elements. ${ }^{73}$ Correspondingly, other Partners, vis-à-vis Russia, shall also keep 100 percent of their own elements. As such, Russia has more rights following its obligations. The MOUs provide the precise percentages of other Partners' utilization rights in Russia's elements. ${ }^{74}$ This approach has effectively avoided the divergent views on evaluating Russia's infrastructure elements upon its participation. ${ }^{75}$ China may adopt the same approach when China attaches its infrastructure elements to the ISS.

Similarly, China shall "be responsible for the share of the common system operations costs or activities corresponding to the operation of the elements it provides, ${ }^{76}$ and bear financial responsibilities for costs or activities arising from the operation and maintenance of its own elements. The existing financial contributions are closely linked to "agreement among all the Partners on the setting-up of a fleet of spacecraft supplied by four of the five Partners to meet all of the Station's transport requirements." ${ }^{77}$ With the final flight of Space Shuttle Atlantis in July $2011{ }^{78}$ the retirement of the space shuttle will no doubt have some influence on the maintenance of the ISS. When Americans first flew aboard the Soyuz, it had a long and impressive history of reliability and of docking with other spacecrafts. ${ }^{79}$

71 J. Johnson-Freese, China's Manned Space Program: What is that all about?, 6 Harv. Asia PaCific Rev. 28 (2002).

72 The 1998 IGA art. 9.1. One important example of user elements is the ISS laboratories.

73 A. Farand, Legal Environment for Exploitation of the International Space Station (ISS), in IntERnATIONAL SPACE State: The Next Space Marketplace 147 (G. Haskell \& M. Rycroft eds., 2000).

74 Id.

75 Id.

76 The 1998 IGA art 9.3(a).

77 Supra note 73.

78 D. Chow, Shuttle Atlantis Docks at Space Station for Last Time, SPACE.com, Jul. 10, 2011, available at http:// www.space.com/12230-shuttle-atlantis-space-station-final-docking.html (last visited on Apr. 6, 2013).

79 D. Day, The China Gambit, The SPACE Rev., Jan. 21, 2008, available at http://www.thespacereview.com/ 
If China successfully spacewalks and rendezvous, and demonstrates this latter capability multiple times, then China would have much more to offer at less risk to the United States. ${ }^{80}$ In this regard, China's mature launching facilities and services could provide an impetus to the advancement of the ISS' transportation system. Consequently, China's possible partnership in the ISS will significantly affect the existing share of financial contributions; China's deployment of its own space shuttle may offset its share of common system operations responsibilities. ${ }^{81}$

Another matter asking urgent consideration is technical standards. Partner States provide elements, materials, and technologies for the operation of the ISS. However, different States might have different standards. If China participates in the ISS, it will need to consult with other Partner States on mutually acceptable criteria for the safety and control of relevant programs. ${ }^{82}$

Crews are essential to the daily operation of the ISS. It is necessary for China to consider the active participation of its own crews on board the ISS. It would largely depend on the accommodating capabilities of the ISS and the availability of the rescue vehicle. Furthermore, once China attaches its own infrastructure elements to the ISS, it should also consider the number of crewmembers needed for the operations and maintenance of this extra part. ${ }^{83}$

\section{Future Considerations}

When it comes to possible legal issues, the following must be taken into account. First, a more effective ISS legal regime will be necessary to further democratize the US-dominating ISS. This touches on the various administrative provisions related to management, operation, and utilization of the ISS. While the ISS is co-led by the US and Russia under the current framework, the US still takes up the leading role with the power to make many final decisions. For example, the MOUs generally

\footnotetext{
article/1042/1 (last visited on Apr. 6, 2013).

81 J. Oberg, China Takes Aim at the Space Station, NBCNews, available at http://www.nbcnews.com/id/3077826/ (last visited on Apr. 6, 2013).

82 F. Slaze, Cooperation in Space-The International Space Station Benefits from ISO Standards, ISO, Oct. 5, 2011, available at $\mathrm{http} / /$ www.iso.org/iso/home/news_index/news_archive/news.htm?refid=Ref1555 (last visited on Apr. 6 , 2013).

83 AFP, China's Space Mission Shows Growing Ambitions, KhileEj Times, Jun. 18, 2012, available at http:// www.khaleejtimes.com/kt-article-display-1.asp?xfile=/data/specialfeature/2012/June/specialfeature_June23. $\mathrm{xml \& section=}=$ specialfeature (last visited on Apr. 6, 2013).
}

$80 \quad$ Id. 
provide that the Multilateral Coordination Board ("MCB"), which is the highest-level cooperative body responsible for coordinating activities and formulating guidelines, comprises representatives from each of the Partners with the NASA as the chair. ${ }^{84}$ This arrangement partly explains the reason why the US has been able to exclude China from participating in the ISS. ${ }^{85}$

China must decide if such managing arrangement will work for it. The question lies in how to insert China into the whole managing and operational framework of the ISS. If the ISS is essentially a cooperative venture, Chinese crew onboard the ISS should have the opportunity to freely visit any part of the ISS and use the facilities of any other Partner States for scientific research. China's role should be commensurate with the contributions it could make to the ISS. Thus, a democratic system should be amenable to all the Partner States, including China. The current provisions on criminal jurisdiction, command, and control have largely democratized the cooperative framework for the ISS Partners, and thus can continue to apply once China becomes an ISS Partner. ${ }^{86}$ As such, China will have guaranteed criminal jurisdiction over its own national and retain jurisdiction and control over its own elements and personnel in or on board the ISS. While the US retains the overall control over the ISS due to its ground activities, China shall similarly keep control over activities carried out within its territorial jurisdiction, subject to overall coordination for the ISS operations.

As mentioned above, the extradition provision is meaningful to China. However, one simple paragraph on the issue is obviously too vague and general when real problems come up. In this aspect, it would be advisable to refer to the Code of Conduct for ISS Crews concerning the understanding of misconduct or crimes in specific circumstance of outer space. ${ }^{87}$ Unfortunately, even under the Code of Conduct, the Partner States have had difficulties in reaching consensus on certain terms. Because the States had failed to define the legal concept of 'harassment,' e.g., a general statement was inserted in the Code of Conduct in the end. ${ }^{88}$ It merely says:

84 The Russian Space Agency-NASA MOU art 8.1.b.

85 J. Ashe, Space Station Alpha: International Shining Star or Legal Black Hole?, 9 Temp. InT'L \& Comp. L. J. 348 (1995).

86 The 1998 IGA art. 5 \& 22.

87 See Code of Conduct for the International Space Station Crew (2000), available at http://download.esa.int/docs/ ECSL/ISS_Crew_Code_of_Conduct.pdf(last visited on Apr. 9, 2013).

88 A. Farand, The Code of Conduct for International Space Station Crews, 105 ESA BulLETIN 66 (2011), available at http://www.esa.int/esapub/bulletin/bullet105/bul105_6.pdf (last visited on Apr. 6, 2013). 
ISS Crew Members' conduct shall be such as to maintain a harmonious and cohesive relationship among the ISS Crew Members and an appropriate level of mutual confidence and respect through an interactive, participative and relationship-oriented approach which duly takes into account the international and multicultural nature of the crew and mission. ${ }^{89}$

It would thus necessary to continue the work of trying to come up with clear applicable scope for the extradition provision.

Second, it is important to reach mutual understanding on the term 'peaceful purposes' in the IGA. ${ }^{90}$ Currently, there is no clear definition yet; it can be taken to mean and encompass a range of terms such as non-military, civil use and non-aggressiveness. ${ }^{91}$ This might create problems in view of the US' suspicion over China's motives in developing its space programs. ${ }^{92}$ In order to avoid misunderstanding, it would be necessary for both parties to reach some consensus on the term 'peaceful purposes.' Although it has been discussed in the international arena for many years, no consensus has been reached yet. Thus, a pragmatic approach is required to adopt. 'Transparency' would be an important principle to dissipate suspicions over peaceful use of outer space. ${ }^{93}$ A stable mechanism could be to set up periodic meetings for Partner States to exchange views and discuss issues of common concerns. The successful functioning of the ISS relies on mutual trust. Dialogues can help build trust and strengthen cooperation among Partner States. $^{94}$

The transparency principle should also apply to the provision and exchange of data and materials. Some basic rules have been provided in the IGA 1998. Further research is needed on how to add transparency to the application of those data and materials. This includes the issue of intellectual property protection and fair use of the materials. The EU has largely unified the intellectual property regime. It would be thus necessary to look into the regime at the international level and make sure that inventions in the ISS should be protected in most jurisdictions around the world. All existing international intellectual property treaties such as the 1883 Paris

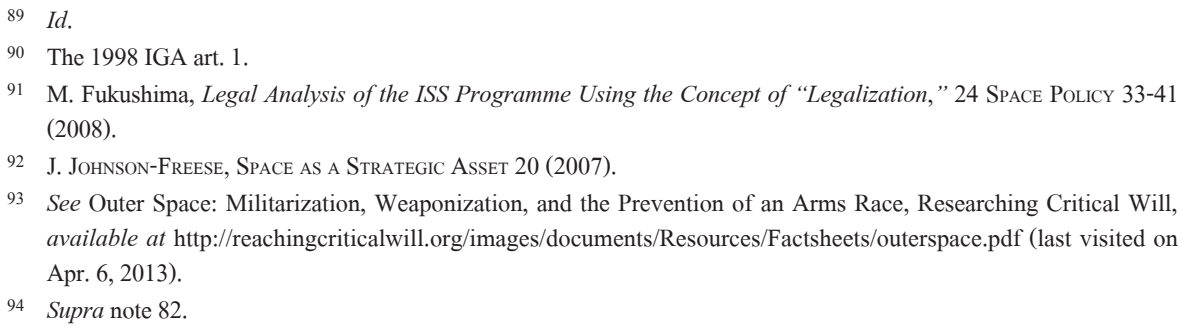


Convention and the Patent Cooperation Treaty could provide a basis for a protective regime. ${ }^{95}$

Third, while the IGA defines well the liability issue, it fails to provide rules on State responsibility. The Partner States are expected to properly carry out their functions under the IGA with 'good faith' in this cooperative project. Nonetheless, clear provisions is necessary on State responsibilities for failing to implement the IGA properly. It is possible, according to the IGA, for a non-complying State to voluntarily withdraw from the cooperative framework. ${ }^{96}$ However, questions remain about what can be done if the non-complying State does not withdraw. Without other binding measures in place, restrictions over the utilization rights could be one possible way out. $^{97}$

Fourth, closely connected with issue of vague language in the IGA, a possible body should serve as a neutral party to resolve such disagreements or disputes with regards to interpretation. Ensuring continued cooperation among Partner States should be the most important guideline for the dispute settlement mechanism. As such, a committee could be set up comprising of senior representatives or officials designated by the Partner States. Aside from trying to resolve disputes and make decisions by consensus, the Committee can also be designated to carry out functions such as the supervision of the implementation of the IGA provisions; interpreting the IGA provisions; and drafting proposals to amend the IGA. ${ }^{98}$

A corollary from the above is that there should be a binding dispute settlement mechanism, possibly with a third neutral party granted authority to finally settle issues. Dispute settlement was one of the most contentious issues during the 1985-1988 negotiations on the ISS project. ${ }^{99}$ The US insisted that because of the sheer magnitude of the project and the enormous economic investment involved, it was in the parties' interests to settle their disputes at the lowest possible hierarchical level. ${ }^{100}$ Without third-party dispute settlement, two major adverse consequences would arise. ${ }^{101}$ One is the stagnation of the implementation of intergovernmental commitments. ${ }^{102}$ The

95 See Intellectual Property and Space Activities: Issue paper prepared by the International Bureau of WIPO, Apr. 2004, available at $\mathrm{http} / /$ www.wipo.int/patent-law/en/developments/pdf/ip_space.pdf (last visited on Apr. 6, 2013).

96 The 1998 IGA art. 28.

97 I. Bouvet, Space for Entrepreneurs and Tourists: Some Legal Issues, in Beyond the International Space Station: The Future of Human Spaceflight 242 (M. Rycroft ed., 2002).

98 K. Madders, A New Force at a New Frontier: Europe's Development in the Space Field in the Light of its Main Actors, Policies, Law, and Activities from its Beginnings up to the Present 186 (1997).

99 G. Goh, Dispute Settlement in International Space Law: A Multi-Door Courthouse for Outer Space 61 (2007).

100 Id.

101 Supra note 91 , at 40.

102 Id. 
other is the perpetration of legal uncertainty among private operators seeking to transact business in an unsettled legal environment. ${ }^{103}$ While friendly consultation provides an amicable way to resolve possible disputes and helps maintain a good relationship among the Partner States, ${ }^{104}$ the possibility of larger disputes should not be ignored. Thus, specific rules and dispute resolution system will determine how to resolve such disputes. At the moment, a binding arbitration mechanism would be useful to the ultimate resolution of disputes. While allowing some flexibility in the dispute resolution process, the parties concerned will be obliged to comply with any decision made by the arbitral body. This shall be helpful to the sustainable development for the cooperation among Partner States. ${ }^{105}$

Last, but not least, in view of the "One Country, Two System"106 arrangement in China, policymakers will also consider the feasibility of applying Hong Kong and Macau laws in certain space modules registered by Hong Kong or Macau. ${ }^{107}$ According to the Basic Laws for Hong Kong and Macau, foreign affairs and relationships are exclusive area reserved to the Central People's Government (“CPG"). ${ }^{108}$ China will carry out diplomatic functions by negotiating with the ISS Partner States reaching or acceding to the IGA. The Chinese government should make a declaration concerning the status of Hong Kong and Macau in the regime. Generally, non-governmental body from these two regions can be specially permitted by the CPG to carry out some activities in the ISS or send some modules to the ISS. Nonetheless, the Chinese laws shall generally apply. This shall be in compliance with the position of Basic Laws on foreign relationship. ${ }^{109}$

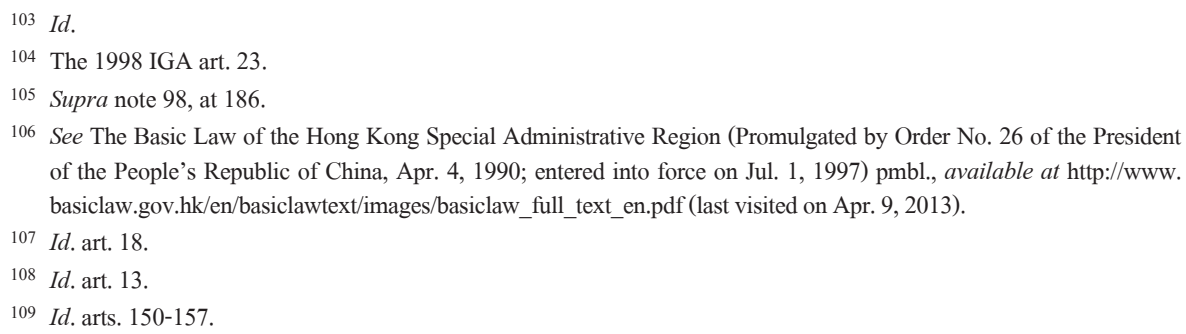




\section{Conclusion}

This paper has examined the legal issues which may arise with the China's participation in the ISS in the future. The ISS is the first permanently inhabited outpost in outer space. A team of rotating international crew carries out commercial, scientific and technological research onboard the ISS. ${ }^{110}$

The ISS provides an ideal example of space commercialization. Having few clear rules in place to regulate space commercial activities, China's participation in the ISS shall hopefully provide an impetus for an in-depth study of the legal issues involved in space commercialization. The legal issues should be considered from at least three perspectives: legal framework, institutional, and operational issue. For the discussions on the above legal issues, Russian participation in the ISS in 1998 can be referred to. On the whole, we should uphold the principle of balancing rights and obligations in China's participation.

China's participation in the ISS also provides an excellent opportunity for both China and the ISS Partner States to carry out international space cooperation at a large scale and at a higher level. Before its participation, however, China should prepare for all possible technical and legal problems, especially when the current Partner States still hold suspicions over China's participation. China should start seriously considering why these countries hold such suspicions and how China can dissipate these suspicions. Moreover, China should more proactively examine the existing ISS documents and study how to further improve the current IGA and improve the ISS cooperative framework. As a result, China shall move ahead in two-stage processes: first on the possibility of participation; second on the modification and improvement of the current ISS regime. These two-stage processes are inter-related; China's participation shall largely rely on how the future ISS regime can benefit China and fit in China's further development in space technologies and programs. In turn, China's participation shall unavoidably lead to work on revising and improving the current regime. Thus, these two-stage processes should be considered concurrently. Also, China must prepare for both processes and move forward for possible negotiations with the Partner States.

On the one hand, China's participation shall contribute the sustainable development of the ISS. The ISS can make use of "the expertise and potential of

110 J. Camilla et al., International Space Station, available at http://www.oglethorpe.edu/faculty/ m_rulison/Astronomy/ Group/Fall\%2099/international_space_station.htm (last visited on Apr. 6, 2013). 
the China's space program and Chinese financial support." ${ }^{\text {"111 }}$ As one of the major space powers, China's participation will take the ISS one step further towards a real multi-national cooperative projects in the peaceful and commercial use of outer space. China, on the other hand, should grasp the best opportunity to start negotiations and learn from the rich experience of the ISS Partner States. By expanding the scope and deepening the level of international space cooperation, China shall establish solid foundation for its own space station in the future and realizing more colorful dreams towards conquering outer space.

111 V. Zaborsky, China's Bid to Join the MTCR: Cost and Benefits, 2 Asian EXPort Control Observer 13 (2004), available at $\mathrm{http}: / / \mathrm{cns} . \mathrm{miis}$. edu/observer/pdfs/aeco_0406.pdf(last visited on Apr. 9, 2013). 